\title{
Maggot Extract Interrupts Bacterial Biofilm Formation and Maturation in Combination with Antibiotics by Reducing the Expression of Virulence Genes
}

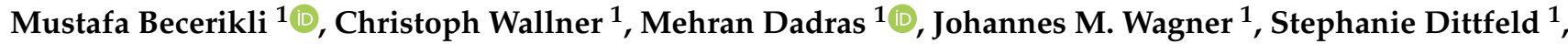 \\ Birger Jettkant $^{2}$, Falk Gestmann ${ }^{3}{ }^{\mathbb{D}}$, Heinz Mehlhorn ${ }^{3}$, Tim Mehlhorn-Diehl ${ }^{3}$, Marcus Lehnhardt ${ }^{1}$ \\ and Björn Behr 1,*
}

Citation: Becerikli, M.; Wallner, C.; Dadras, M.; Wagner, J.M.; Dittfeld, S.; Jettkant, B.; Gestmann, F.; Mehlhorn, H.; Mehlhorn-Diehl, T.; Lehnhardt, M.; et al. Maggot Extract Interrupts Bacterial Biofilm Formation and Maturation in Combination with Antibiotics by Reducing the Expression of Virulence Genes. Life 2022, 12, 237. https://doi.org/ 10.3390/life12020237

Academic Editor: Cheng-Yen Kao

Received: 28 December 2021

Accepted: 2 February 2022

Published: 4 February 2022

Publisher's Note: MDPI stays neutral with regard to jurisdictional claims in published maps and institutional affiliations.

Copyright: (C) 2022 by the authors. Licensee MDPI, Basel, Switzerland. This article is an open access article distributed under the terms and conditions of the Creative Commons Attribution (CC BY) license (https:// creativecommons.org/licenses/by/ $4.0 /)$.
1 Department of Plastic and Reconstructive Surgery, BG University Hospital Bergmannsheil, Ruhr-University Bochum, 44789 Bochum, Germany; mustafa.becerikli@rub.de (M.B.); c.wallner88@gmail.com (C.W.); mdadras@outlook.com (M.D.); max.jay.wagner@googlemail.com (J.M.W.); dittfeld.stephanie@gmail.com (S.D.); marcus.lehnhardt@bergmannsheil.de (M.L.)

2 Department of General and Trauma Surgery, BG University Hospital Bergmannsheil, Ruhr-University Bochum, 44789 Bochum, Germany; jettkant@ipa-dguv.de

3 Alpha-Biocare GmbH, 41468 Neuss, Germany; gestmann@alphabiocare.de (F.G.); mehlhorn@uni-duesseldorf.de (H.M.); tim.mehlhorn@alphabiocare.de (T.M.-D.)

* Correspondence: bjorn.behr@rub.de; Tel.: +49-234-302-3443

\begin{abstract}
Biofilms are aggregates of bacteria encased in an extracellular polymer matrix that acts as a diffusion barrier protecting the microbial community. Bacterial communication occurs by small signaling molecules called quorum sensing (QS) factors, which are involved in the activation of virulence genes and formation of biofilms. Larvae of the green bottle blowfly Lucilia sericata remove necrotic tissue by mechanical action (debridement) and proteolytic digestion. We produced a freezedried storable powder from larval extract and investigated its therapeutic effect on biofilms. Larval extract in concentrations of 6 and $12 \mathrm{mg} / \mathrm{mL}$ in combination with $0.5 \%$ antibiotics $(\hat{=} 50 \mathrm{U} / \mathrm{mL}$ penicillin and $50 \mu \mathrm{g} / \mathrm{mL}$ streptomycin) diminished free-floating (planktonic) Pseudomonas aeruginosa maintenance, while it showed no effect on Staphylococcus aureus and was not toxic to dermal cells. We established an ex vivo human dermal wound model. Larval extract in concentrations of 24 and $75 \mathrm{mg} / \mathrm{mL}$ in the presence of antibiotics (0.5\%) significantly destroyed the biofilm stability of both P. aeruginosa and S. aureus biofilms. Furthermore, SEM analyses revealed crack and gap formations on $P$. aeruginosa. biofilm surface and decreased expression of $P$. aeruginosa biofilm maturation and virulence genes (lasR, $r h l R$ and $r h l A$ ) was observed after treatment by larval extract in combination with antibiotics.
\end{abstract}

Keywords: maggot extract; Lucilia sericata; biofilm; virulence genes; Pseudomonas aeruginosa; Staphylococcus aureus; antibiotic resistance

\section{Introduction}

Bacterial biofilms are complex structures consisting of microbial communities encased in extracellular polymer matrix containing polysaccharides, proteins, and nucleic acids [1,2]. Although antibiotics still show great therapeutic effects on individual, free-floating (planktonic) bacteria, their effect on biofilms is inherently negligible [3]. One mechanism of biofilm resistance to antibiotic agents is that the biofilm layer acts as a diffusion barrier reducing the rate of antibiotic penetration into the full depth of biofilms [4,5]. Even the long-term use of antibiotics in high concentrations does not guarantee the elimination of microorganisms within biofilms [6]. A further mechanism is that extracellular matrix protects chronic wound biofilms from the inflammatory processes of the host, which plays a significant role in wound healing $[7,8]$. Mature biofilms can persist in humans for many months or even over the lifetime of the host [9]. Biofilm formations on chronic wounds 
constitute a major clinical problem given the provision of ideal environmental conditions for biofilm aggregation. Attachment of bacteria is supported by necrotic tissue and debris, while infection of wounds is accelerated by impaired host immune response [10,11]. After the attachment of planktonic bacteria, micro-colonies consisting of primary colonizers rapidly develop and begin to produce the extracellular matrix and to express the biofilmphenotype [12]. Furthermore, bacteria within the micro-colony begin to release quorum sensing (QS) factors, small molecular weight signaling molecules. QS is a bacterial density dependent form of cell-cell communication, involving a hierarchy of signaling molecules. It plays a key role in the activation of virulence genes and development, formation and maturation of biofilms. QS molecules have been identified in many bacterial species, and QS mutants are not able to form structurally normal biofilms [12,13].

The Gram-negative bacteria Pseudomonas aeruginosa (P. aeruginosa) and Gram-positive bacteria Staphylococcus aureus (S. aureus) are mostly responsible for delayed healing and infection in both acute and chronic wounds and are widely known to cause chronic biofilmbased infections in their hosts [14,15]. QS mechanisms of P. aeruginosa and S. aureus have been extensively studied. The initial P. aeruginosa QS phase is regulated by two tightly controlled pathways, namely Las (lasR/lasI genes) and Rhl (rhlR/rhlI genes) systems [16]. Analyses of 40 clinical isolates of $P$. aeruginosa revealed that $100 \%$ of the isolates expressed the lasR and $r h l R$ genes [17]. The Las system is at the top of the QS cascade. The lasR gene codes the transcription factor, which is responsible for the activation of numerous target genes related to QS in $P$. aeruginosa, amongst other things rhlR (and further downstream factors like $r h l A)$, which encode the second QS pathway $[17,18]$.

Maggot debridement therapy is an alternative medication option of infected chronic non-healing wounds and was introduced into clinical practice by Baer in 1931 [19]. It is widely accepted that larvae of the green bottle blowfly Lucilia sericata (L. sericata) remove necrotic tissue by mechanical action (debridement) and by proteolytic digestion [20]. However, some points are disadvantageous in classic maggot debridement therapy: (1) pain during the maggot movements on the wound, (2) an annoying smell of maggot excrements, (3) logistical problems, (4) the larvae are freshly inserted and must be replaced after a few days and (5) a general feeling of disgust in the patient. To avoid these negative features, freeze-dried extracts were produced by homogenization and extraction from maggots to obtain it as a storable powder.

In this study, the effect of L. sericata larval extract (trade name Larveel ${ }^{\circledR}$ ) in combination with antibiotics was investigated on biofilm formation and maturation and antibiotic resistance of $P$. aeruginosa and $S$. aureus. For this approach, in vitro co-culture experiments with human dermal cells were performed and an ex vivo human dermal wound model was used. Furthermore, biofilm surface analysis by scanning electron microscopy and measurement of gene expression of virulence factors was performed with and without Larveel $^{\circledR}$ treatment. Larval extract in the presence of antibiotics significantly destroyed biofilm stability of $P$. aeruginosa and $S$. aureus and significantly decreased expression of $P$. aeruginosa biofilm maturation and virulence genes (lasR, rhlR and $r h l A)$.

\section{Materials and Methods}

\subsection{Lucilia Sericata Larvae Extract}

Larveel ${ }^{\circledR}$, a sterile powder made from $100 \%$ larvae of L. sericata (Figure S1), was produced by Alpha-Biocare GmbH (Neuss, Germany) by its own patented process (patent: DE 102005061246 A1). In short, third-instar larvae of L. sericata grown under GMP conditions were homogenized, heated, sterile filtered, freeze-dried and sterilized with gamma radiation. Larveel ${ }^{\circledR}$ powder of one vial $(0.15 \mathrm{~g})$ was reconstituted in $2 \mathrm{~mL}$ sterile DMEM (according to the tested conditions with or without antibiotics) to generate $100 \%$ Larveel ${ }^{\circledR}$ stock solution ( $\hat{=} 75 \mathrm{mg} / \mathrm{mL}$ ). Further dilutions were made by diluting the stock solution with medium or Luria-Bertani (LB) broth (Carl Roth GmbH, Karlsruhe, Germany). 


\subsection{Bacteria Cultures}

Gram-negative bacterial strain P. aeruginosa PAO1 (P. aeruginosa) and Gram-positive bacterial strain S. aureus 6850 (S. aureus), consequently expressing green fluorescent protein (gfp) and red fluorescent protein (rfp), respectively, were kindly provided by Prof. Dr. Katharina Riedel (Institute of Microbiology, University of Greifswald, Greifswald, Germany). Bacteria were inoculated into LB broth and incubated overnight at $37^{\circ} \mathrm{C}$. A total of $1 \mathrm{~mL}$ of overnight culture was transferred to $5 \mathrm{~mL}$ fresh LB broth for 4 hours. Cultures were centrifuged and bacterial pellets were dissolved in phosphate-buffered saline (PBS, Gibco, Thermo Fisher Scientific, Waltham, MA, USA) or LB broth and were diluted to $\mathrm{OD}_{600}=0.5$.

\subsection{Isolation of Human Cutaneous Cells}

Isolation of human fibroblasts and keratinocytes was performed as previously described and with some modifications [21,22]. Skin explants were obtained from adult healthy patients undergoing abdominoplasty surgery. Briefly, skin was washed several times in PBS and subcutaneous fat was excised. Subsequently, skin was completely covered with freshly prepared $0.2 \%$ dispase solution ( 4.7 units $/ \mathrm{mL}$, Gibco). After overnight incubation at $4{ }^{\circ} \mathrm{C}$, epidermis was detached and incubated in a trypsin/EDTA solution $(0.05 \% / 0.02 \%$, PAN-Biotech GmbH, Aidenbach, Germany). Harvested keratinocytes were cultivated in keratinocyte growth medium (Keratinocyte Growth Medium 2, PromoCell, Heidelberg, Germany) at $37{ }^{\circ} \mathrm{C}$ with $5 \% \mathrm{CO}_{2}$. The dermis was completely covered with collagenase type- 2 solution ( 3000 units $/ \mathrm{mL}$, Gibco) and incubated overnight at $37^{\circ} \mathrm{C}$. Cell suspension was filtered through a cell strainer, centrifuged and harvested fibroblasts were cultured in DMEM (Gibco), containing 10\% FBS (Gibco) and $1 \%$ antibiotics ( $\hat{=} 100 \mathrm{U} / \mathrm{mL}$ penicillin and $100 \mu \mathrm{g} / \mathrm{mL}$ streptomycin, PAN-Biotech $\mathrm{GmbH}$ ), here entitled fibroblast medium, at $37{ }^{\circ} \mathrm{C}$ with $5 \% \mathrm{CO}_{2}$. Media were changed every second day.

\subsection{Cell Co-Culture with Bacteria In Vitro}

Isolated fibroblasts $\left(2 \times 10^{4}\right.$ cells $)$ and keratinocytes $\left(3 \times 10^{4}\right.$ cells $)$ were seeded in confluent co-culture in $500 \mu \mathrm{L}$ of co-culture medium (1:1 Keratinocyte Growth Medium and fibroblast medium, with $0.5 \%$ as the final antibiotics concentration) into wells of 24-well plates and cultivated overnight. This allows a rudimentary and fast co-cultivation model of fibroblasts and keratinocytes over a few days. The two antibiotics penicillin and streptomycin were used because they are predominantly applied in cell culture, are non-toxic to the examined dermal cells and are effective against both used bacterial strains. On the next day, the co-culture medium was replaced by a fresh medium and inoculated with $5 \mu \mathrm{L}$ of P. aeruginosa $\left(\mathrm{OD}_{600}=0.5\right)$ or $10 \mu \mathrm{L}$ of $S$. aureus $\left(\mathrm{OD}_{600}=0.5\right)$ or both bacterial strains. Larveel ${ }^{\circledR}$ was added in different concentrations $(0,3,6$ and $12 \mathrm{mg} / \mathrm{mL})$. After a 24-hour incubation, nuclei were counterstained with the fluorescence DNA dye DAPI and co-cultures were analyzed by an inverse Olympus X83 microscope ( $P$. aeruginosa green fluorescence, $S$. aureus red fluorescence). Afterwards, co-cultures were fixed in $4 \%$ paraformaldehyde (Sigma-Aldrich, St. Louis, MO, USA) overnight at $4{ }^{\circ} \mathrm{C}$ and Gram staining was performed according to manufacturer's instructions. Pictures of dermal cells (fibroblasts and keratinocytes) were taken and quantification was performed using the software Photoshop (Adobe Systems, San Jose, CA, USA). Three random regions of interest were selected $(1000 \times 1000 \mathrm{Px})$ and non-colonized area was semi-automatically quantified by unstained pixels via magic wand tool (tolerance $40 \%$; noncontiguous).

\subsection{Skin Tissue Culture, Epidermal Wounding and Infection of Ex Vivo Dermal Model}

Skin tissue culture was performed as previously described and with some modifications [23]. Skin explants were obtained from adult healthy patients undergoing abdominoplasty surgery. Briefly, skin was washed several times in phosphate buffered saline (PBS) and subcutaneous fat was excised. Tissue was sliced into rectangular pieces of about $1 \times 1 \mathrm{~cm}$ and placed into 12-well tissue culture inserts (Sarstedt, Nümbrecht, Germany) with the epithelial-side upward. Inserts were transferred to 12-well cell culture plates 
filled with $1.2 \mathrm{~mL}$ of medium DMEM (Gibco), supplemented with $10 \%$ fetal bovine serum (FBS) (Thermo Fisher Scientific), 1\% antibiotics (penicillin (100 U/mL) and streptomycin $(100 \mu \mathrm{g} / \mathrm{mL})$, PAN-Biotech $\mathrm{GmbH})$, and Amphotericin B $(2.5 \mu \mathrm{g} / \mathrm{mL}$, PAN-Biotech GmbH) for antimycotic medication. Samples were cultured at the air-liquid interphase at $37{ }^{\circ} \mathrm{C}$ in a humidified atmosphere containing $5 \% \mathrm{CO}_{2}$ for $24 \mathrm{~h}$. Accordingly, culture medium was changed with DMEM containing $10 \%$ FBS and $1 \%$ antibiotics.

For wounding, skin was punched standardized $1 \mathrm{~mm}$ in depth using a $6 \mathrm{~mm} \varnothing$ biopsy punching knife. A punched piece was removed carefully by lifting it with forceps and cutting it off with scissors, without penetrating the skin tissue. Wound infection was performed by application of $10 \mu \mathrm{L}$ of bacterial solution $\left(\mathrm{OD}_{600}=1.0\right)$ on the wound, and at the same time, addition of $10 \mu \mathrm{L}$ of the medium containing 48 or $150 \mathrm{mg} / \mathrm{mL} \mathrm{Larveel}{ }^{\circledR}$ and $1 \%$ antibiotics to obtain a final concentration of 24 or $75 \mathrm{mg} / \mathrm{mL}$ Larveel ${ }^{\circledR}$ and $0.5 \%$ antibiotics. For control, $10 \mu \mathrm{L}$ of the medium without Larveel ${ }^{\circledR}$ but with antibiotics was used. Again, samples were cultured at $37^{\circ} \mathrm{C}$ in a humidified atmosphere containing $5 \%$ $\mathrm{CO}_{2}$ for $24 \mathrm{~h}$. Afterwards, to remove unstable fragments of biofilms, samples were washed in a standardized manner with defined volume (P. aeruginosa: $500 \mu \mathrm{L}$, S. aureus: $100 \mu \mathrm{L})$ of PBS application once before samples were fixed with $4 \%$ paraformaldehyde (PFA) at $4{ }^{\circ} \mathrm{C}$ overnight. Accordingly, after washing three times with PBS, samples were incubated in $10 \%$ saccharose at $4{ }^{\circ} \mathrm{C}$ overnight before preparing frozen sections. Sections were Gram stained according to standard protocols. Pictures were taken and the number of pixels of biofilms was quantified using the software Photoshop as described. The biofilm area without Larveel ${ }^{\circledR}$ treatment was defined as $100 \%$. All experiments were repeated seven times. Results of all experiments were given as mean \pm SD.

\subsection{Scanning Electron Microscopy (SEM)}

SEM was performed as previously described [24] with some modification. A total of $50 \mu \mathrm{L}$ of LB broth with P. aeruginosa $\left(\mathrm{OD}_{600}=1.0\right)$ was added to $50 \mu \mathrm{L}$ of LB broth supplemented with the appropriate final concentrations of Larvee ${ }^{\circledR}, 0.2 \%$ antibiotics, and a final glucose concentration of $0.25 \%$ as a carbon source on small titanium specimens that were placed into wells of 6-well plates and were incubated for $48 \mathrm{~h}$ at $37^{\circ} \mathrm{C}$. Bacteria were fixed in $3 \%$ glutaraldehyde at $4{ }^{\circ} \mathrm{C}$ overnight, followed by dehydration using an ethanol series. After sticking onto metal stubs and gold/palladium $(60 \% / 40 \%)$ coating in a sputter coater (Emitech K500×, Gala Instruments, Bad Schwalbach, Germany), specimens were analyzed by SEM (DSM 962, Zeiss, Oberkochen, Germany).

\subsection{RNA Preparation and cDNA Synthesis}

RNA isolation and cDNA synthesis was performed as previously described [25] with some modification. Briefly, $50 \mu \mathrm{L}$ of LB broth with P. aeruginosa $\left(\mathrm{OD}_{600}=0.5\right)$ was added to $50 \mu \mathrm{L}$ of LB broth supplemented with $0.25 \%$ glucose in a final concentration in 96-well plates at $37^{\circ} \mathrm{C}$. Depending on the experimental conditions, antibiotics $(0.25 \%$ final concentration) or Larveel ${ }^{\circledR}(24 \mathrm{mg} / \mathrm{mL}$ final concentration) were added. After $48 \mathrm{~h}, \mathrm{RNA}$ was isolated separately from planktonic bacteria in LB supernatant and biofilms attached on plate surfaces by an RNAprotect Bacteria Reagent and RNeasy Protect Bacteria Kit (Qiagen, Hilden, Germany) according to manufacturer's instructions. Purified RNA was eluted in $30 \mu \mathrm{L}$ of RNase-free water. For reverse transcription, $1 \mu \mathrm{g}$ total RNA per reaction was transcribed using the High-Capacity cDNA Reverse Transcription Kit with RNase inhibitor (Thermo Fisher Scientific) following the manufacturer's instructions.

\subsection{Quantitative Real-Time PCR (qRT-PCR)}

Quantitative relative gene expression was determined on Applied Biosystems StepOnePlus real-time PCR System using SYBR Green master mix (Thermo Fisher Scientific) and primers (TIB Molbiol, Berlin, Germany) listed in Table S1 [26]. For quantitative analysis, $2 \mu \mathrm{L}$ of cDNA, $2 \mu \mathrm{L} \mathrm{H}{ }_{2} \mathrm{O}, 1 \mu \mathrm{L}$ of primer mix $(0.5 \mu \mathrm{M}$ each sense and antisense) and $5 \mu \mathrm{L}$ of SYBR Green Mastermix in a total volume of $10 \mu \mathrm{L}$ were used for each reaction. The 
cycling conditions were as follows: $95^{\circ} \mathrm{C}$ for $10 \mathrm{~min}, 40$ cycles consisting of $95^{\circ} \mathrm{C}$ for $5 \mathrm{~s}$, annealing $60{ }^{\circ} \mathrm{C}$ for $30 \mathrm{~s}, 72{ }^{\circ} \mathrm{C}$ for $10 \mathrm{~s}$; followed by a melting point analysis: $65-95{ }^{\circ} \mathrm{C}$ at a ramp speed of $0.5^{\circ} \mathrm{C} / \mathrm{s}$; and finally, a cooling phase. Data were analyzed according to the manufacturer's $\Delta \Delta C_{t}$ method (Applied Biosystems, Thermo Fisher Scientific, Waltham, MA, USA). Samples were normalized to the oprF gene. Results are shown relatively in relation to gene expression without Larveel ${ }^{\circledR}$ and antibiotic treatment, that was defined as 1.0 .

\subsection{Statistical Analysis}

All experiments were repeated at least three times. Results of all experiments were given as mean \pm SD. Results without Larveel ${ }^{\circledR}$ treatment were defined as $100 \%$ in all relative results. Statistical analyses were performed by unpaired 2-tailed Student's $t$-test. $p$-values $<0.05$ were considered statistically significant and indicated in the figures as follows: *: $p<0.05 ;{ }^{* *}: p<0.01$; and ${ }^{* *}: p<0.001$.

\section{Results}

\subsection{Cell Protective Effect of Larveel ${ }^{\circledR}$ towards Bacterial Infection in Combination with Antibiotics}

To analyze the effect of Larvee ${ }^{\circledR}$ on cells infected with Gram-negative and Grampositive bacteria, fibroblast and keratinocyte co-cultures were infected with $P$. aeruginosa or $S$. aureus or both strains. Additionally, medium was supplemented with $0.5 \%$ antibiotics and different concentrations of Larveel ${ }^{\circledR}$. Dermal cells inoculated with P. aeruginosa showed strong green fluorescence indicating massive bacterial growth in the medium (Figure 1, top). Furthermore, diffuse and destroyed fibroblast and keratinocyte cell nuclei (in blue) were observed in these wells. Addition of Larveel ${ }^{\circledR}$ in concentrations of 6 and $12 \mathrm{mg} / \mathrm{mL}$ diminished green $P$. aeruginosa fluorescence in a concentration-dependent manner. In contrast, $S$. aureus was observed as red fluorescent dots (Figure 1, middle), thus a vigorous bacterial proliferation was not observed with $0.5 \%$ antibiotics. No striking differences in S. aureus distribution and red fluorescence intensity after Larveel ${ }^{\circledR}$ application were seen in this experimental approach. P. aeruginosa and $S$. aureus co-culture with dermal cells exhibited an overgrowth of P. aeruginosa in the medium (Figure 1, bottom). Similar to the top line, the addition of Larveel ${ }^{\circledR}$ in concentrations of 6 and $12 \mathrm{mg} / \mathrm{mL}$ diminished the green $P$. aeruginosa fluorescence. Co-culture approaches with bacteria and with $0 \%$ antibiotics exhibited completely cloudy media due to severe bacterial growth and were discarded (not shown). Thus, we decided to use $0.5 \%$ antibiotics, on the one hand to allow the bacteria to grow, but on the other hand, to prevent uncontrolled expansion. A basal concentration of $0.5 \%$ antibiotics was constantly necessary in co-culture experiments to keep the eukaryotic cells alive and maintain the experimental conditions.

Analyses of dermal cells after infection with bacteria by Gram staining revealed a toxic effect of $P$. aeruginosa on fibroblasts and keratinocytes, and thus destroyed cell structures were recognized (Figure 2). S. aureus showed no observable effect on dermal cells. In summary, Larveel ${ }^{\circledR}$ concentrations of 6 and $12 \mathrm{mg} / \mathrm{mL}$ in combination with $0.5 \%$ antibiotics showed no toxic effect on dermal cells, rather protective effect towards bacterial infections. 


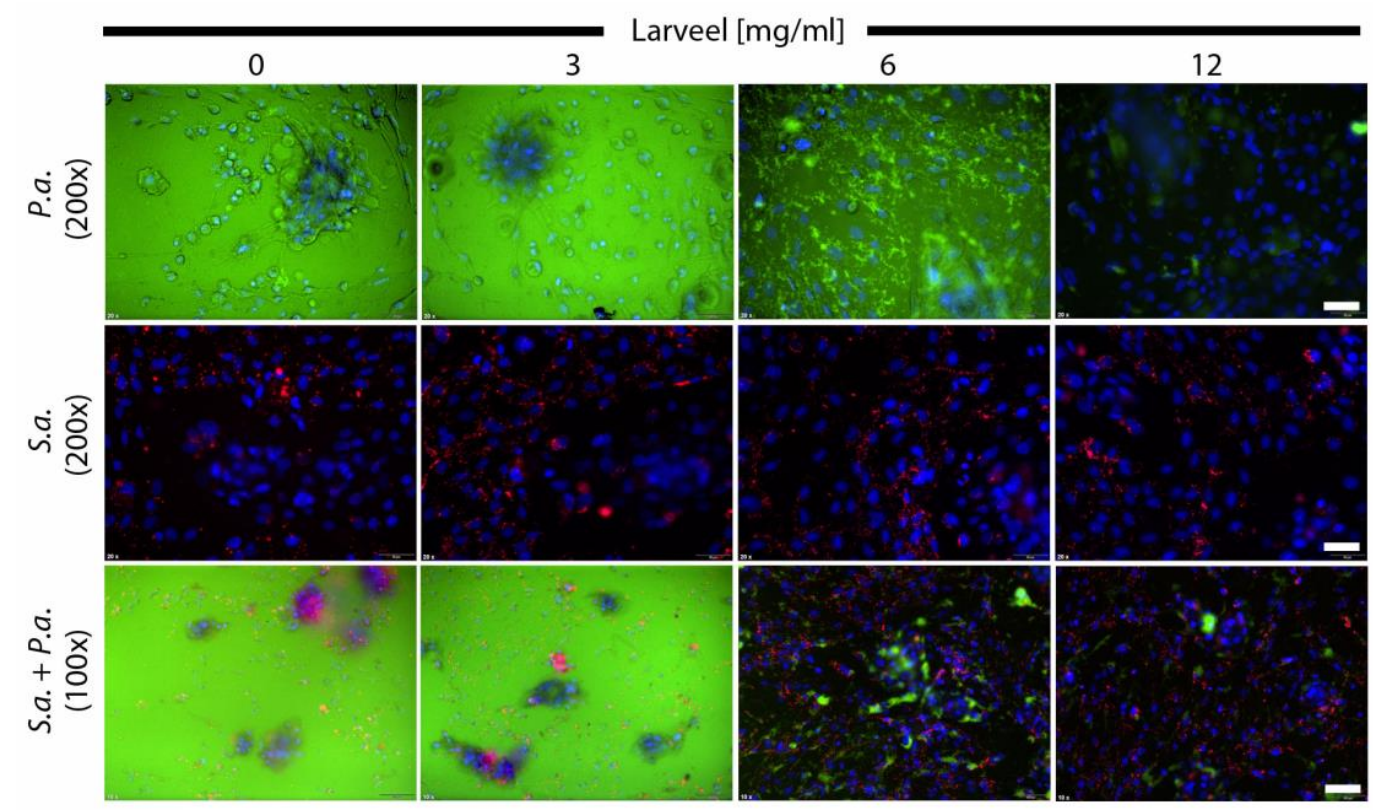

Figure 1. Fluorescence microscopy of cells infected with bacteria. Fibroblast and keratinocyte cocultures were infected with P. aeruginosa and S. aureus in medium with $0.5 \%$ antibiotics and were supplemented with different Larveel ${ }^{\circledR}$ concentrations for $24 \mathrm{~h}$. P. aeruginosa is shown in green fluorescence (gfp), S. aureus in red fluorescence ( $\mathrm{rfp}$ ) and nuclei of dermal cells are shown in blue (DAPI). Nuclei of keratinocytes were arranged in clusters. P.a.: P. aeruginosa; S.a.: S. aureus. Top and middle line $200 \times$ magnification, scale bar: $50 \mu \mathrm{m}$; bottom line $100 \times$ magnification, scale bar: $100 \mu \mathrm{m}$.
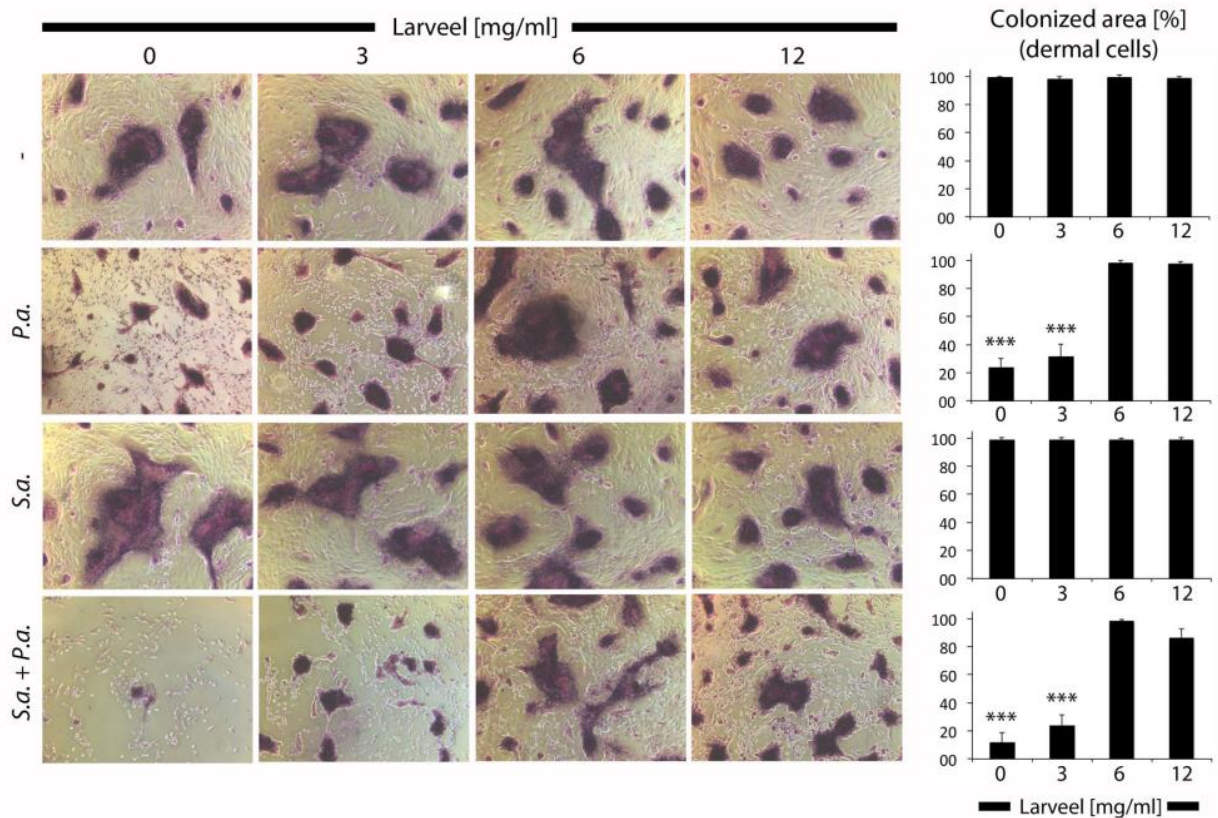

Figure 2. Gram staining of cells infected with bacteria. Fibroblast and keratinocyte co-cultures infected with $P$. aeruginosa and S. aureus in medium with $0.5 \%$ antibiotics and different Larveel ${ }^{\circledR}$ concentrations were stained $24 \mathrm{~h}$ after incubation. Pictures of dermal cells were taken $(50 \times$ magnification) and number of pixels was quantified. P.a.: P. aeruginosa; S.a.: S. aureus. Colonized area by dermal cells without bacterial inoculation and Larveel ${ }^{\circledR}$ treatment was defined as $100 \%$. Results of all experiments were given as mean $\pm \mathrm{SD}$. ${ }^{* * *} p<0.001$. 


\subsection{Generation of an Ex Vivo Human Dermal Wound Model}

In order to analyze Larvee ${ }^{\circledR}$ treatment depending biofilm stability and for quantification of the effect of Larveel ${ }^{\circledR}$ on biofilm removal, an ex vivo human dermal wound model was established. Initially, ex vivo experiments were carried out as previously described [23] and were later modified. Human dermal tissue pieces cultivated in 12-well tissue culture plates in air-liquid interphase were biopsy punched in a standardized manner and infected for $24 \mathrm{~h}$ (Figure 3). Gram staining revealed reddish Gram-negative P. aeruginosa and deep purple Gram-positive S. aureus biofilms on the skin tissue (Figure 3E,F).
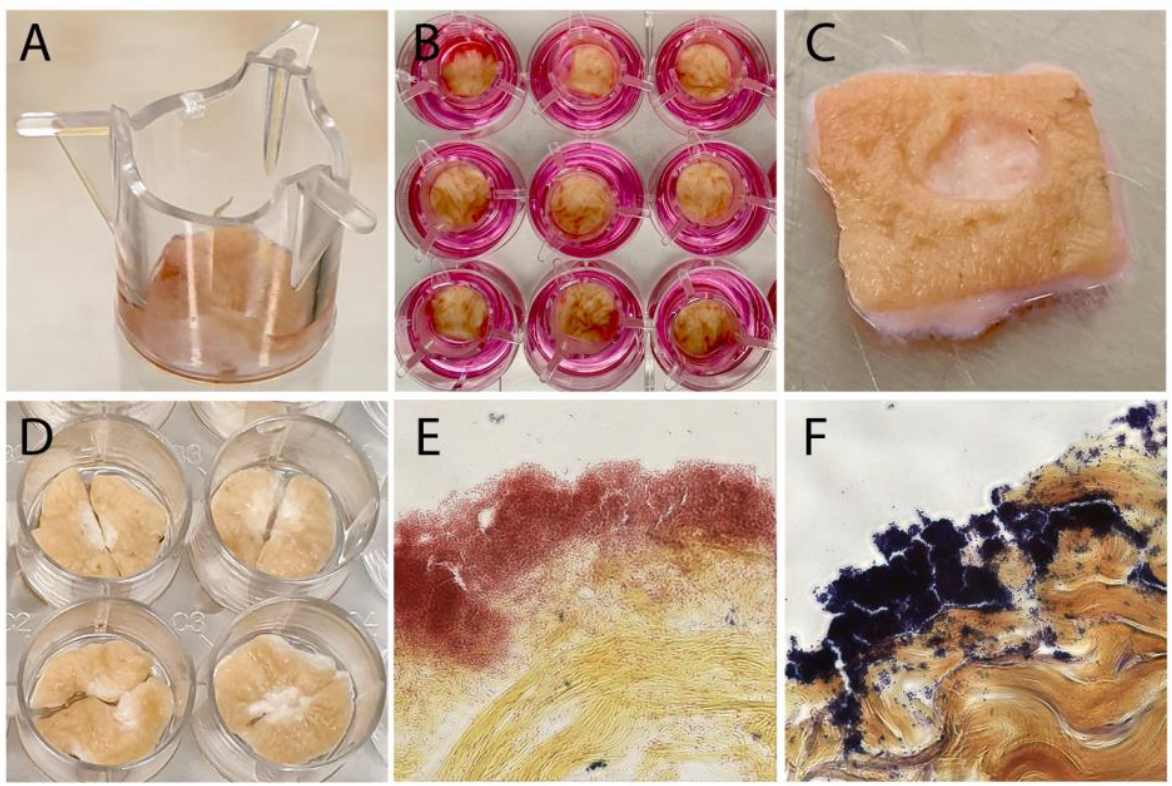

Figure 3. Ex vivo human dermal wound model. (A-D) Dermal tissue pieces were cultivated in 12-well tissue culture plates in air-liquid interphase and were standardized biopsy punched. Gram staining of (E) P. aeruginosa and (F) S. aureus biofilms on infected skin wounds (400× magnification).

\subsection{Impaired Biofilm Maturation and Stability by Larvee ${ }^{\circledR}$ Treatment in the Ex Vivo Human Dermal Wound Model}

After establishment of an experimental dermal model with clinical relevance, we performed Larveel ${ }^{\circledR}$ treatment with two therapeutic concentrations and examined biofilm maturation and stability. For this approach, based on the routine wound care, in which infected wounds are cleaned, samples were standardized washed with defined volume, distance and speed of PBS application one-time before fixation and staining. P. aeruginosa produced thick and robust biofilms, which also infiltrated the infected tissue. Untreated biofilms remained unchanged after washing. Treatment with 24 and $75 \mathrm{mg} / \mathrm{mL}$ Larveel $^{\circledR}$ solution (in presence of $0.5 \%$ antibiotics) significantly destroyed biofilm stability depending on Larveel ${ }^{\circledR}$ concentration and flaky biofilm structures were observed (Figure 4). Compared to $P$. aeruginosa biofilms, $S$. aureus biofilms were more superficial and slighter. Treatment with both Larveel ${ }^{\circledR}$ concentrations significantly removed remaining biofilms and only small bacterial spots were observed (Figure 4). 

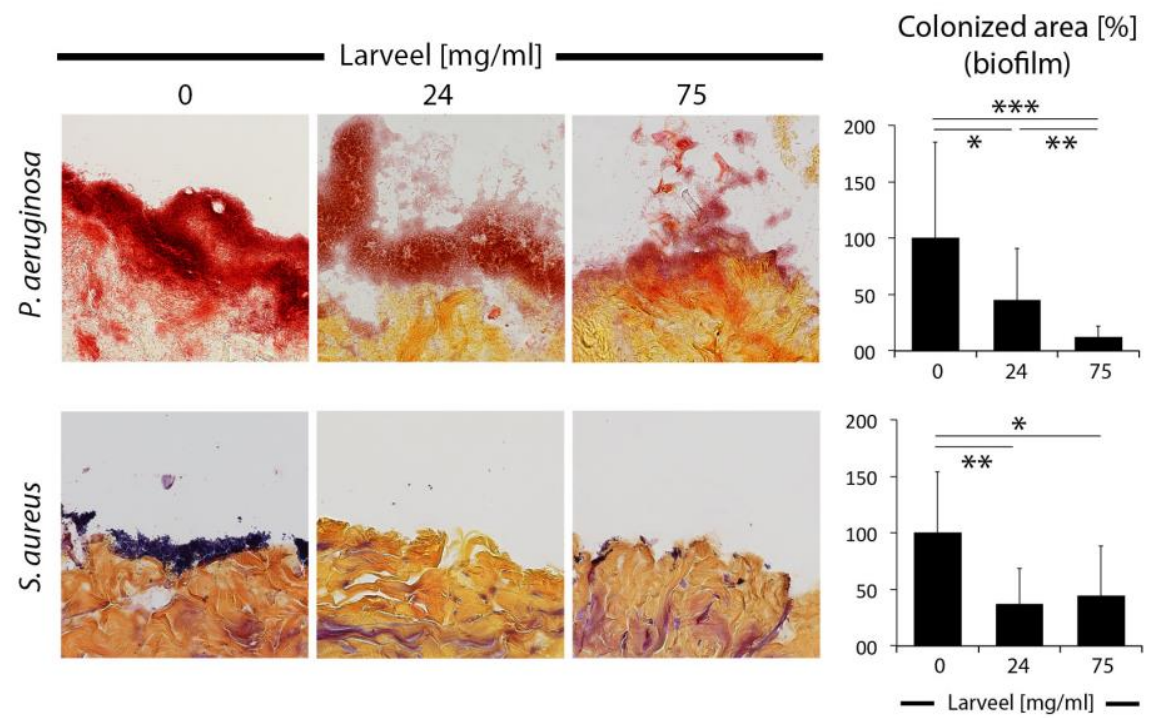

Figure 4. Destruction and removal of biofilms by Larveel ${ }^{\circledR}$ treatment in the ex vivo human dermal wound model. Skin wounds were infected and treated at the same time with Larveel ${ }^{\circledR}$ and $0.5 \%$ antibiotics for $24 \mathrm{~h}$. After PBS washing one-time by standardized manner, samples were fixed and Gram stained. Pictures were taken $(200 \times$ magnification) and number of pixels of biofilms was quantified. Biofilm area without Larvee ${ }^{\circledR}$ treatment was defined as $100 \%$. Results of all experiments were given as mean $\pm \mathrm{SD}{ }^{*} p<0.05,{ }^{* *} p<0.01,{ }^{* * *} p<0.001$.

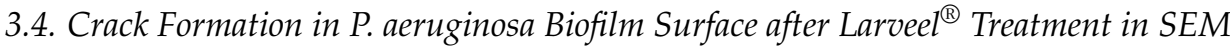

To find clues regarding why biofilms were easier removed after Larveel ${ }^{\circledR}$ treatment, we performed SEM analyses of P. aeruginosa biofilms. Compared to untreated samples, Larveel ${ }^{\circledR}$ addition resulted in cracks and formation of gaps in P. aeruginosa biofilm surface $(200 \times$, $3000 \times$ magnification). At higher resolution $(20,000 \times)$, filament-like extracellular matrix structures that seem to connect bacterial cells with each other and with their environment were observed. In contrast, the surface of single bacteria in the Larveel ${ }^{\circledR}$ treated group appeared to be smoother. Extracellular matrix structures observed on bacterial surface disappeared after Larveel ${ }^{\circledR}$ treatment (Figure 5). 

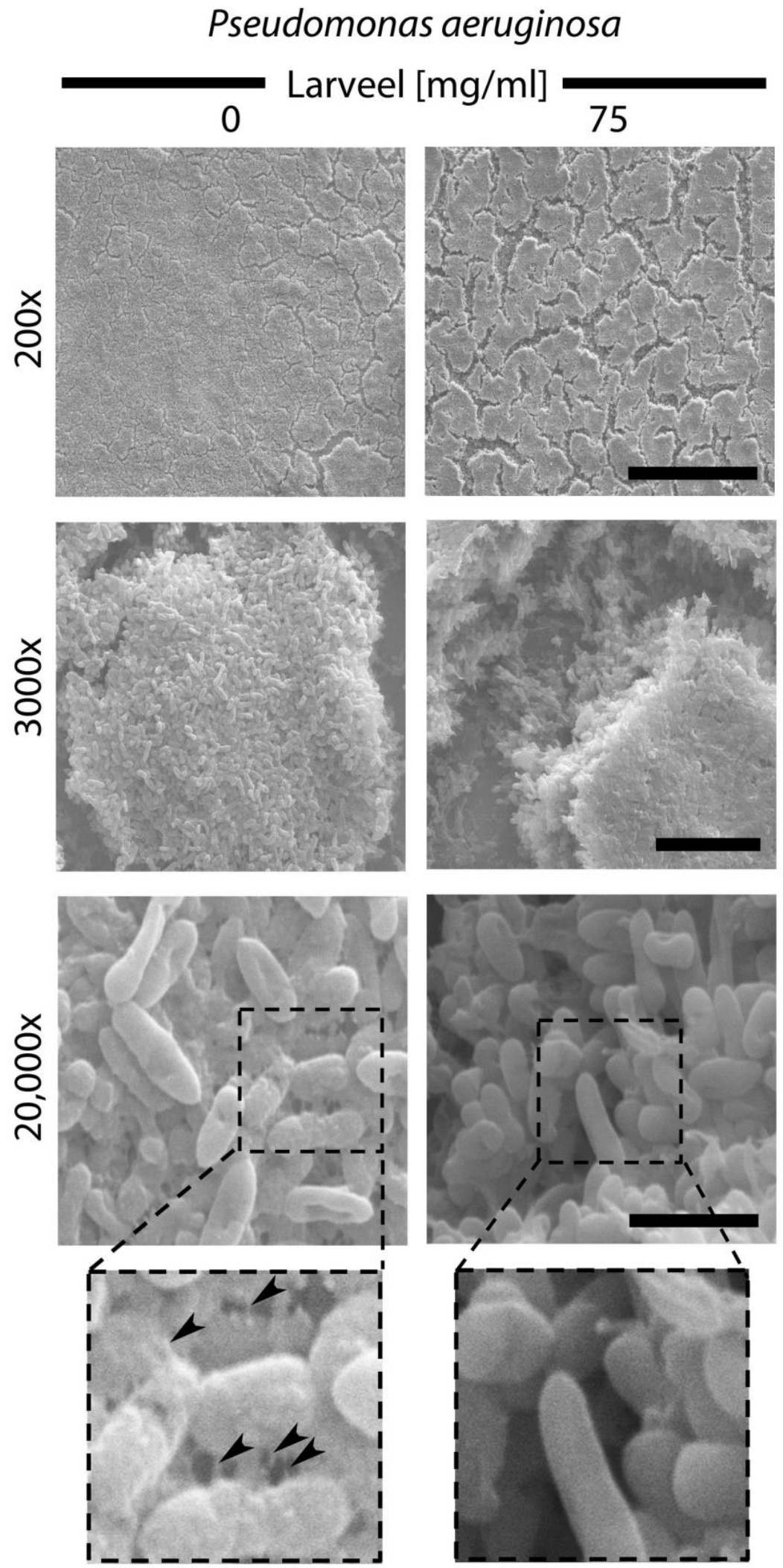

Figure 5. SEM analyses of $P$. aeruginosa biofilm surface. Biofilm production and maturation was performed for $48 \mathrm{~h}$ with and without Larveel ${ }^{\circledR}$ treatment. Cracks were observable on the surface of biofilms of treated P. aeruginosa (top). Filament-like extracellular matrix structures on the surface of untreated bacteria are indicated by arrowheads (down; box: enlarged sections). Scale bars: $200 \times$ : $200 \mu \mathrm{m} ; 3000 \times$ : $10 \mu \mathrm{m} ; 20,000 \times: 2 \mu \mathrm{m}$. 


\subsection{Decreased Expression of Biofilm Maturation and Virulence Genes after Larveel ${ }^{\circledR}$ Treatment}

RNA was isolated separately from planktonic bacteria in LB supernatant and biofilms attached on plate surfaces. Interestingly, supernatant with planktonic bacteria was more viscous in untreated controls, whereas after Larvee ${ }^{\circledR}$ treatment supernatant was more fluid (data not shown). To investigate both pathways of P. aeruginosa QS initial phase, gene expression of one factor of each pathway (lasR and $r h l R$ ) were quantified by qRT-PCR. Additionally, gene expression of $r h l R$ downstream factor $r h l A$ was measured. Both antibiotics used in this study (penicillin and streptomycin) showed no effect on gene expression of the analyzed QS-associated genes when they were used alone without Larveel ${ }^{\circledR}$. Gene expression of QS activation factor las $R$ was significantly decreased after a combination of antibiotics and Larveel ${ }^{\circledR}$ in planktonic bacteria as well as in biofilms (Figure 6). Additionally, Larveel ${ }^{\circledR}$ alone without antibiotics significantly inhibited lasR expression in planktonic bacteria. Similarly, gene expression of $r h l R$ was also significantly diminished after combination therapy, but addition of Larveel ${ }^{\circledR}$ alone without antibiotics also decreased $r h l R$ gene expression in both planktonic bacteria and biofilms. Gene expression of $r h l A$ was not affected by antibiotics or Larveel ${ }^{\circledR}$ solely. Only the combination of both resulted in significantly decreased $r h l A$ gene expression in planktonic bacteria as well as in biofilms (Figure 6).
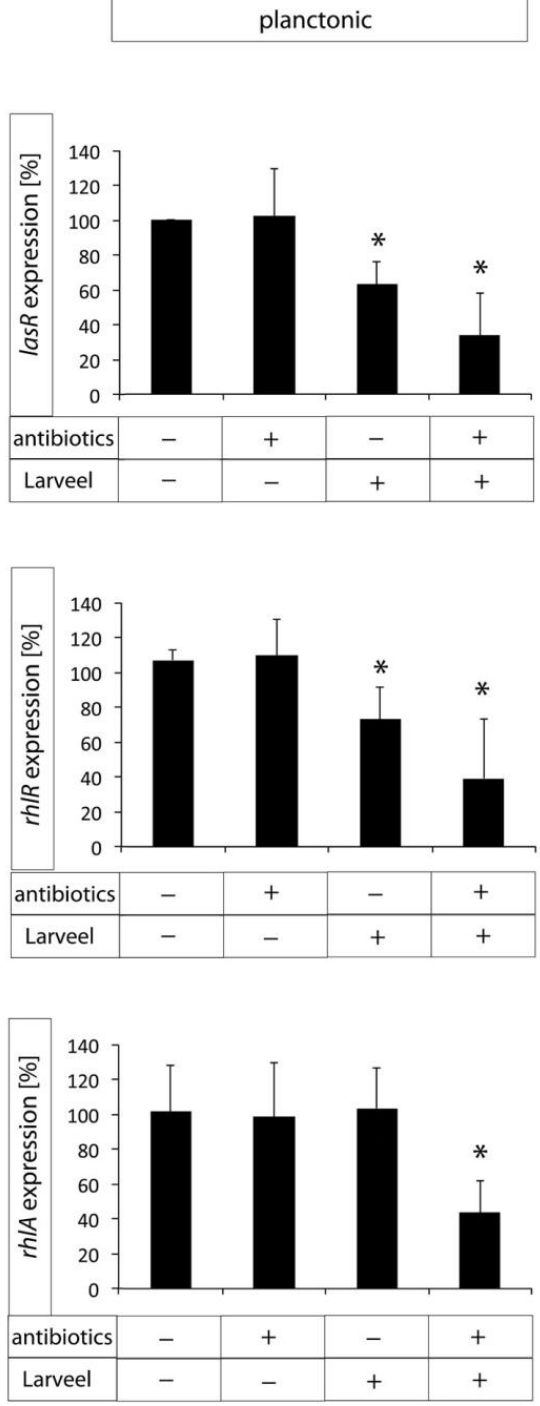
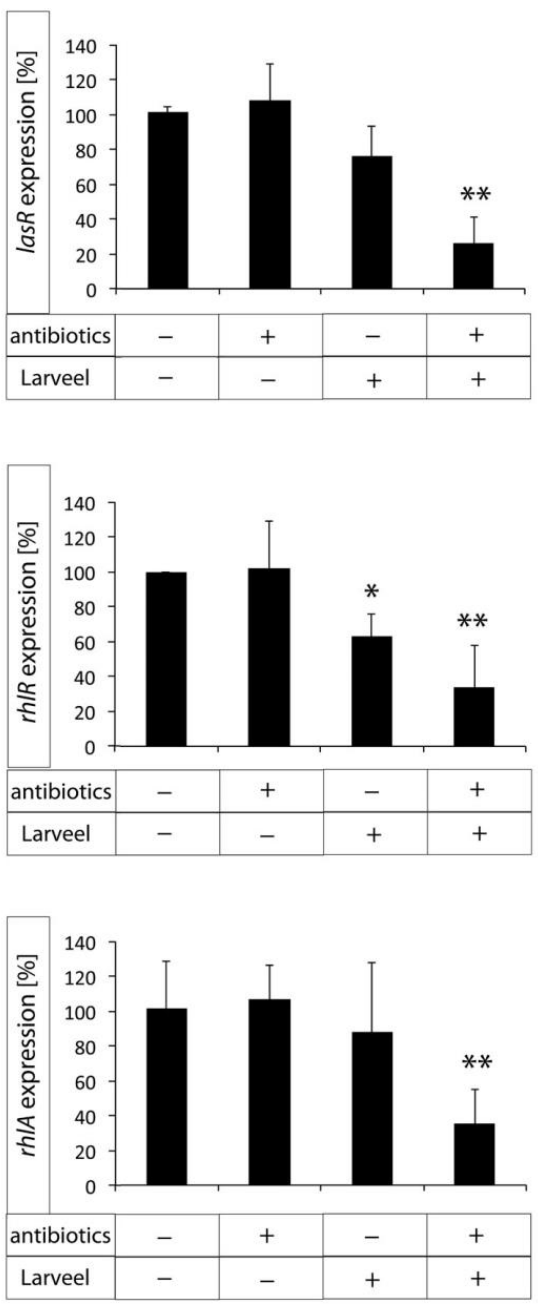

Figure 6. Gene expression of biofilm maturation and virulence genes measured by qRT-PCR after treatment with antibiotics $(0.25 \%)$ or / and Larveel ${ }^{\circledR}(24 \mathrm{mg} / \mathrm{mL})$. Gene expression without antibiotics and Larvee $\mathrm{l}^{\circledR}$ was defined as $100 \%$. Results of all experiments were given as mean \pm SD. $\left({ }^{*} p<0.05\right.$, ** $p<0.01)$. 


\section{Discussion}

The steady increase in antibiotic resistance of bacteria present on wounds is a major problem that will become more dramatic in the near future. Extensive use of antibiotics creates an evolutionary stress response in the bacterial population that over time leads to a rapid evolution of resistant strains. Thus, the amount of antibiotics used must be drastically reduced to avoid further antimicrobial resistance.

Larvae/maggots are natural products and maggot debridement therapy could support the wound treatment without the use of antibiotics in high concentrations and severe side effects. The majority of studies concerning the effect of maggots on eukaryotic cells or bacteria revealed no influence on dermal cell viability, proliferation, migration and angiogenesis or no direct antibacterial effect in vitro. However, in clinical observations maggot therapy proved to be successful $[27,28]$. We also observed no toxic effect of Larveel ${ }^{\circledR}$ on dermal cells. Furthermore, a cell protective effect of Larveel ${ }^{\circledR}$ towards bacterial infection in combination with antibiotics was determined.

Larveel $^{\circledR}$ is already being used successfully in clinical applications in some developing countries at a concentration of $75 \mathrm{mg} / \mathrm{mL}$ without seeing any toxic effects on the patient ([29] and clinical observation). It is generally known that a therapeutic in vitro concentration is not enough in an in vivo experiment. In in vivo experiments, significantly higher dosages are required. Based on this fact and our previous experiments, we opted for reducing the concentration in our in vitro experimental setup and we opted for lower concentrations and reduced it to $3-12 \mathrm{mg} / \mathrm{mL}$. Because the ex vivo setup is close to clinical in vivo usage, we decided to increase the Larveel ${ }^{\circledR}$ concentration according to the clinical concentration. Furthermore, in order to clearly show the effect on the biofilms, in SEM examinations we decided to use the usual clinical concentration of $75 \mathrm{mg} / \mathrm{mL}$.

Even planktonic bacteria in suspensions are mechanically coupled to each other, this coupling gets intensified in biofilms [30]. Biofilms survive despite antibiotic therapy or the innate and adaptive immune system of the patient. Consequently, many biofilm infections are difficult to treat efficiently and the demand for research of new treatment strategies is of particular clinical relevance. One problem at this point is that biofilms protect bacterial infections against antibiotic treatment regiments. To overcome this, biofilms have to be made permeable. We observed significantly more crack and gap formation in $P$. aeruginosa biofilm surfaces after Larveel ${ }^{\circledR}$ treatment and less extracellular matrix structures on higher resolution. In previous studies, it was observed that short-chain fatty acids inhibited biofilm formation [31]. Utilizing gas chromatography-mass spectrometry (GC-MS) analysis (data not shown), we detected isovaleric acid (3-methylbutanoic acid), a short-chain fatty acid, is contained in Larvee ${ }^{\circledR}$. Furthermore, it is assumed that Larveel ${ }^{\circledR}$ contains various Damino acids due to the fly maggots used [32,33]. Some D-amino acids exhibited synergistic anti-biofilm activity in combination with antibiotics [34]. Thus, treatment with Larveel ${ }^{\circledR}$ in the presence of antibiotics significantly interrupted biofilm formation and maturation by a synergistic effect, but Larveel ${ }^{\circledR}$ alone could not achieve this result.

$P$. aeruginosa and $S$. aureus are one the most common cause of cutaneous infections $[35,36]$. Experiments with $P$. aeruginosa and $S$. aureus revealed that both bacterial strains could coexist initially, but in late-stage co-cultures, P. aeruginosa predominates in the community and eliminates $S$. aureus $[37,38]$. To avoid this predomination in our experimental period, we started the experiments with more S. aureus. Moreover, in the present study, we focused on QS of P. aeruginosa. QS is a bacterial cell-to-cell communication that involves a hierarchy of signaling molecules, which in pathogenic bacteria is associated with virulence regulation and biofilm formation [39]. It allows bacteria to synchronously adjust behavior in response to changes in the population density and species composition of the environment community $[40,41]$. Furthermore, QS enables bacteria to communicate with other species as well [42]. Considering that more than $10 \%$ of P. aeruginosa genes are regulated by QS, the critical role of QS in physiological adaptation is more comprehensible [43]. These genes are mainly involved in virulence factor production, motility-sessility switch and biofilm development and antibiotic resistance mechanisms [43]. 
Analogously, mechanisms interfering with bacterial cell-cell communication evolved, which was termed quorum quenching [42]. A variety of small-molecule inhibitors of QS signaling were discovered and were tested as novel antimicrobial therapies [44-47]. However, there are still typical major obstacles in the transition from the bench to the clinic, such as lack of potency in animal models, toxicity, stability and delivery [48]. Furthermore, some antibiotics, such as azithromycin and ceftazidime or chemical compounds, were observed to decrease the expression of QS-regulated virulence factors in P. aeruginosa [49-51]. In our approach, we determined decreased expression of biofilm maturation and virulence genes in P. aeruginosa after Larveel ${ }^{\circledR}$ treatment. To our knowledge, this is the first-time that reduced gene expression of QS factors by maggot larvae extract is described.

Larveel $^{\circledR}$ is designed to be applied in saline solution directly onto the wounded or rather infected tissue before it is covered with a dressing. To reduce the time required to change wound dressings and to simplify the procedure, sterile and storable wound cover containing Larveel ${ }^{\circledR}$ has been developed (Figure S2). The sheets passed all necessary quality criteria and initial studies on patients with chronic wounds are in progress.

In summary, this study demonstrates that larval extract of the green bottle blowfly Lucilia sericata interrupts biofilm formation and maturation of P. aeruginosa and S. aureus in synergistic combination with antibiotics. No toxic effect of Larveel ${ }^{\circledR}$ on dermal cells was observed. Larvee ${ }^{\circledR}$ application resulted in crack formation in P. aeruginosa biofilm surface and reduction of extracellular matrix structures on bacterial surfaces. Finally, a significant decrease of gene expression of virulence genes was detected.

\section{Conclusions}

Bacterial biofilms on chronic wounds constitute a serious health burden. From a clinical point of view, efficient treatment of chronic wounds attacked by these complex structures belongs to one of the most difficult complications. Despite little effects of antibiotics on biofilms, increasing resistance to antibiotics is one of the main global concerns at present. Thus, any approach that can help to tackle this task should be taken into consideration. In this study, we demonstrated that Larveel ${ }^{\circledR}$, an extract of the green bottle blowfly Lucilia sericata, destroys biofilm stability of P. aeruginosa and S. aureus in combination with antibiotics. Furthermore, P. aeruginosa. biofilms reveal crack formation on surface and decreased expression of virulence genes after therapy. In this context, we showed that local treatment of bacterial biofilms on chronic wounds with Larveel ${ }^{\circledR}$ in combination with antibiotics might be considered a good candidate for successful therapy of biofilms.

Supplementary Materials: The following are available online at https:/ / www.mdpi.com/article/10 $.3390 /$ life12020237/s1, Figure S1: Larveel ${ }^{\circledR}$, a sterile powder made from $100 \%$ larvae of Lucilia sericata, Figure S2: Larveel ${ }^{\circledR}$ wound dressing assembled with content of one vial per sheet; Top: front side for wound contact assembled with Larveel ${ }^{\circledR}$; Down: hydrophobic blue backside, Table S1: Primer sequences $\left(5^{\prime} \rightarrow 3^{\prime}\right)$ for qRT-PCR.

Author Contributions: Conceptualization, M.B. and B.B.; Investigation, M.B., C.W., M.D., J.M.W., S.D., B.J., F.G. and T.M.-D.; Resources, M.L.; Writing-original draft preparation, M.B. and B.B.; Writing-review and editing, F.G. and B.B.; Supervision, M.L. and B.B.; Project administration, M.L., H.M. and B.B.; Funding Acquisition, H.M. and B.B. All authors have read and agreed to the published version of the manuscript.

Funding: This research was funded by the Federal Ministry for Economic Affairs and Energy Germany, grant number ZF4048804NK7.

Institutional Review Board Statement: This study was reviewed and approved by the Ethics Committee of the BG University Hospital Bergmannsheil, Ruhr-University Bochum, Germany (permit no. 17-6081-BR).

Informed Consent Statement: Informed consent was obtained from all subjects involved in the study.

Data Availability Statement: The data that supports the findings of this study are available in the figures, tables and the Supplementary Materials of this article. 


\begin{abstract}
Acknowledgments: The authors sincerely thank Katharina Riedel (Institute of Microbiology, University of Greifswald, Greifswald, Germany) for generously providing the bacterial strains and Janine Mertens-Rill (Department of Plastic and Reconstructive Surgery, BG University Hospital Bergmannsheil, Ruhr-University Bochum, Bochum, Germany), Dagmar Tintrup-Lamm (Department of Neurology, Heimer Institute for Muscle Research, University Hospital Bergmannsheil, RuhrUniversity Bochum, Bochum, Germany) and Jürgen Schmidt (Alpha-Biocare GmbH, Neuss, Germany) for their excellent technical support. We acknowledge support by the Open Access Publication Funds of the Ruhr-Universität Bochum.

Conflicts of Interest: Falk Gestmann, Heinz Mehlhorn and Tim Mehlhorn-Diehl are employed or managing director of Alpha-Biocare $\mathrm{GmbH}$ and produced Larveel ${ }^{\circledR}$. Except for this, all authors declare that no conflict of interest and financial disclosure exists. The funders had no role in the design of the study; nor in the collection, analyses, or interpretation of data; in the writing of the manuscript, or in the decision to publish the results.
\end{abstract}

\title{
References
}

1. Hall-Stoodley, L.; Stoodley, P.; Kathju, S.; Høiby, N.; Moser, C.; William Costerton, J.; Moter, A.; Bjarnsholt, T. Towards diagnostic guidelines for biofilm-associated infections. FEMS Immunol. Med. Microbiol. 2012, 65, 127-145. [CrossRef] [PubMed]

2. Høiby, N.; Bjarnsholt, T.; Moser, C.; Bassi, G.L.; Coenye, T.; Donelli, G.; Hall-Stoodley, L.; Holá, V.; Imbert, C.; Kirketerp-Møller, K.; et al. ESCMID* guideline for the diagnosis and treatment of biofilm infections 2014. Clin. Microbiol. Infect. 2015, 21, S1-S25. [CrossRef] [PubMed]

3. Høiby, N.; Bjarnsholt, T.; Givskov, M.; Molin, S.; Ciofu, O. Antibiotic resistance of bacterial biofilms. Int. J. Antimicrob. Agents 2010, 35, 322-332. [CrossRef] [PubMed]

4. Costerton, J.W. Bacterial biofilms: A common cause of persistent infections. Science 1999, 284, 1318-1322. [CrossRef]

5. Mah, T.-F.; Pitts, B.; Pellock, B.; Walker, G.C.; Stewart, P.S.; O’Toole, G.A. A genetic basis for Pseudomonas aeruginosa biofilm antibiotic resistance. Nature 2003, 426, 306-310. [CrossRef] [PubMed]

6. Davies, D. Understanding biofilm resistance to antibacterial agents. Nat. Rev. Drug Discov. 2003, 2, 114-122. [CrossRef] [PubMed]

7. Thurlow, L.R.; Hanke, M.L.; Fritz, T.; Angle, A.; Aldrich, A.; Williams, S.H.; Engebretsen, I.L.; Bayles, K.W.; Horswill, A.R.; Kielian, T. Staphylococcus aureus biofilms prevent macrophage phagocytosis and attenuate inflammation in vivo. J. Immunol. 2011, 186, 6585-6596. [CrossRef] [PubMed]

8. Malic, S.; Hill, K.E.; Playle, R.; Thomas, D.W.; Williams, D.W. In vitro interaction of chronic wound bacteria in biofilms. J. Wound Care 2011, 20, 569-577. [CrossRef]

9. Wolcott, R.D.; Rhoads, D.D. A study of biofilm-based wound management in subjects with critical limb ischaemia. J. Wound Care 2008, 17, 145-155. [CrossRef]

10. Percival, S.L.; Hill, K.E.; Williams, D.W.; Hooper, S.J.; Thomas, D.W.; Costerton, J.W. A review of the scientific evidence for biofilms in wounds. Wound Repair Regen. 2012, 20, 647-657. [CrossRef]

11. Wolcott, R.D.; Rhoads, D.D.; Dowd, S.E. Biofilms and chronic wound inflammation. J. Wound Care 2008, 17, 333-341. [CrossRef]

12. Omar, A.; Wright, J.; Schultz, G.; Burrell, R.; Nadworny, P. Microbial biofilms and chronic wounds. Microorganisms 2017, 5, 9. [CrossRef] [PubMed]

13. Davies, D.G. The involvement of cell-to-cell signals in the development of a bacterial biofilm. Science 1998, 280, 295-298. [CrossRef]

14. Bowler, P.G.; Duerden, B.I.; Armstrong, D.G. Wound microbiology and associated approaches to wound management. Clin. Microbiol. Rev. 2001, 14, 244-269. [CrossRef]

15. Fazli, M.; Bjarnsholt, T.; Kirketerp-Møller, K.; Jørgensen, B.; Andersen, A.S.; Krogfelt, K.A.; Givskov, M.; Tolker-Nielsen, T. Nonrandom distribution of Pseudomonas aeruginosa and Staphylococcus aureus in chronic wounds. J. Clin. Microbiol. 2009, 47, 4084-4089. [CrossRef] [PubMed]

16. Papenfort, K.; Bassler, B.L. Quorum sensing signal-response systems in Gram-negative bacteria. Nat. Rev. Microbiol. 2016, 14, 576-588. [CrossRef]

17. Lima, J.L.d.C.; Alves, L.R.; Jacomé, P.R.L.d.A.; Bezerra Neto, J.P.; Maciel, M.A.V.; Morais, M.M.C.d. Biofilm production by clinical isolates of Pseudomonas aeruginosa and structural changes in LasR protein of isolates non biofilm-producing. Braz. J. Infect. Dis. 2018, 22, 129-136. [CrossRef] [PubMed]

18. Lee, J.; Zhang, L. The hierarchy quorum sensing network in Pseudomonas aeruginosa. Protein Cell 2015, 6, 26-41. [CrossRef]

19. Baer, W.S. The classic: The treatment of chronic osteomyelitis with the maggot (larva of the blow fly). Clin. Orthop. Relat. Res. 2011, 469, 920-944. [CrossRef]

20. Čeřovský, V.; Bém, R. Lucifensins, the insect defensins of biomedical importance: The story behind maggot therapy. Pharmaceuticals 2014, 7, 251-264. [CrossRef]

21. Becerikli, M.; Merwart, B.; Lam, M.C.; Suppelna, P.; Rittig, A.; Mirmohammedsadegh, A.; Stricker, I.; Theiss, C.; Singer, B.B.; Jacobsen, F; et al. EPHB4 tyrosine-kinase receptor expression and biological significance in soft tissue sarcoma. Int. J. Cancer 2015, 136, 1781-1791. [CrossRef] 
22. Harati, K.; Daigeler, A.; Hirsch, T.; Jacobsen, F.; Behr, B.; Wallner, C.; Lehnhardt, M.; Becerikli, M. Tumor-associated fibroblasts promote the proliferation and decrease the doxorubicin sensitivity of liposarcoma cells. Int. J. Mol. Med. 2016, 37, 1535-1541. [CrossRef] [PubMed]

23. Steinstraesser, L.; Sorkin, M.; Niederbichler, A.D.; Becerikli, M.; Stupka, J.; Daigeler, A.; Kesting, M.R.; Stricker, I.; Jacobsen, F.; Schulte, M. A novel human skin chamber model to study wound infection ex vivo. Arch. Dermatol. Res. 2010, 302, $357-365$. [CrossRef]

24. Becerikli, M.; Jaurich, H.; Wallner, C.; Wagner, J.M.; Dadras, M.; Jettkant, B.; Pöhl, F.; Seifert, M.; Jung, O.; Mitevski, B.; et al. P2000-A high-nitrogen austenitic steel for application in bone surgery. PLoS ONE 2019, 14, e0214384. [CrossRef]

25. Becerikli, M.; Jaurich, H.; Schira, J.; Schulte, M.; Döbele, C.; Wallner, C.; Abraham, S.; Wagner, J.M.; Dadras, M.; Kneser, U.; et al. Age-dependent alterations in osteoblast and osteoclast activity in human cancellous bone. J. Cell. Mol. Med. 2017, 21, $2773-2781$. [CrossRef]

26. Gonzalez, M.R.; Fleuchot, B.; Lauciello, L.; Jafari, P.; Applegate, L.A.; Raffoul, W.; Que, Y.-A.; Perron, K. Effect of human burn wound exudate on pseudomonas aeruginosa virulence. mSphere 2016, 1, e00111-15. [CrossRef]

27. Dauros Singorenko, P.; Rosario, R.; Windsor, J.A.; Phillips, A.R.; Blenkiron, C. The transcriptional responses of cultured wound cells to the excretions and secretions of medicinal L ucilia sericata larvae. Wound Repair Regen. 2017, 25, 51-61. [CrossRef] [PubMed]

28. Cazander, G.; van Veen, K.E.B.; Bernards, A.T.; Jukema, G.N. Do maggots have an influence on bacterial growth? A study on the susceptibility of strains of six different bacterial species to maggots of Lucilia sericata and their excretions/secretions. J. Tissue Viability 2009, 18, 80-87. [CrossRef] [PubMed]

29. Mehlhorn, H.; Gestmann, F. Extracts from fly maggots and fly pupae as a "wound healer". In Nature Helps...; Springer: Berlin/Heidelberg, Germany, 2011; pp. 325-348.

30. Sretenovic, S.; Stojković, B.; Dogsa, I.; Kostanjšek, R.; Poberaj, I.; Stopar, D. An early mechanical coupling of planktonic bacteria in dilute suspensions. Nat. Commun. 2017, 8, 213. [CrossRef]

31. Nakamura, K.; O’Neill, A.M.; Williams, M.R.; Cau, L.; Nakatsuji, T.; Horswill, A.R.; Gallo, R.L. Short chain fatty acids produced by Cutibacterium acnes inhibit biofilm formation by Staphylococcus epidermidis. Sci. Rep. 2020, 10, 21237. [CrossRef] [PubMed]

32. Shimada, I. The stimulating effect of fatty acids and amino acid derivatives on the labellar sugar receptor of the fleshfly. J. Gen. Physiol. 1978, 71, 19-36. [CrossRef] [PubMed]

33. Corrigan, J.J.; Srinivasan, N.G. The occurrence of certain D-amino acids in insects*. Biochemistry 1966, 5, 1185-1190. [CrossRef] [PubMed]

34. Warraich, A.A.; Mohammed, A.R.; Perrie, Y.; Hussain, M.; Gibson, H.; Rahman, A. Evaluation of anti-biofilm activity of acidic amino acids and synergy with ciprofloxacin on Staphylococcus aureus biofilms. Sci. Rep. 2020, 10, 9021. [CrossRef]

35. Serra, R.; Grande, R.; Butrico, L.; Rossi, A.; Settimio, U.F.; Caroleo, B.; Amato, B.; Gallelli, L.; de Franciscis, S. Chronic wound infections: The role of Pseudomonas aeruginosa and Staphylococcus aureus. Expert Rev. Anti. Infect. Ther. 2015, 13, 605-613. [CrossRef] [PubMed]

36. Chiller, K.; Selkin, B.A.; Murakawa, G.J. Skin microflora and bacterial infections of the skin. J. Investig. Dermatol. Symp. Proc. 2001, 6, 170-174. [CrossRef]

37. Filkins, L.M.; Graber, J.A.; Olson, D.G.; Dolben, E.L.; Lynd, L.R.; Bhuju, S.; O'Toole, G.A. Coculture of Staphylococcus aureus with Pseudomonas aeruginosa drives $S$. aureus towards fermentative metabolism and reduced viability in a cystic fibrosis model. $J$. Bacteriol. 2015, 197, 2252-2264. [CrossRef]

38. Dalton, T.; Dowd, S.E.; Wolcott, R.D.; Sun, Y.; Watters, C.; Griswold, J.A.; Rumbaugh, K.P. An in vivo polymicrobial biofilm wound infection model to study interspecies interactions. PLoS ONE 2011, 6, e27317. [CrossRef]

39. Moura-Alves, P.; Puyskens, A.; Stinn, A.; Klemm, M.; Guhlich-Bornhof, U.; Dorhoi, A.; Furkert, J.; Kreuchwig, A.; Protze, J.; Lozza, L.; et al. Host monitoring of quorum sensing during Pseudomonas aeruginosa infection. Science 2019, 366, eaaw1629. [CrossRef]

40. Mukherjee, S.; Bassler, B.L. Bacterial quorum sensing in complex and dynamically changing environments. Nat. Rev. Microbiol. 2019, 17, 371-382. [CrossRef]

41. Kolter, R.; Greenberg, E.P. The superficial life of microbes. Nature 2006, 441, 300-302. [CrossRef]

42. Waters, C.M.; Bassler, B.L. QUORUM SENSING: Cell-to-cell communication in bacteria. Annu. Rev. Cell Dev. Biol. 2005, 21, 319-346. [CrossRef]

43. Moradali, M.F.; Ghods, S.; Rehm, B.H.A. Pseudomonas aeruginosa lifestyle: A paradigm for adaptation, survival, and persistence. Front. Cell. Infect. Microbiol. 2017, 7, 39. [CrossRef]

44. Hentzer, M. Attenuation of Pseudomonas aeruginosa virulence by quorum sensing inhibitors. EMBO J. 2003, $22,3803-3815$. [CrossRef] [PubMed]

45. Christensen, Q.H.; Grove, T.L.; Booker, S.J.; Greenberg, E.P. A high-throughput screen for quorum-sensing inhibitors that target acyl-homoserine lactone synthases. Proc. Natl. Acad. Sci. USA 2013, 110, 13815-13820. [CrossRef] [PubMed]

46. O'Loughlin, C.T.; Miller, L.C.; Siryaporn, A.; Drescher, K.; Semmelhack, M.F.; Bassler, B.L. A quorum-sensing inhibitor blocks Pseudomonas aeruginosa virulence and biofilm formation. Proc. Natl. Acad. Sci. USA 2013, 110, 17981-17986. [CrossRef] [PubMed]

47. Starkey, M.; Lepine, F.; Maura, D.; Bandyopadhaya, A.; Lesic, B.; He, J.; Kitao, T.; Righi, V.; Milot, S.; Tzika, A.; et al. Identification of anti-virulence compounds that disrupt quorum-sensing regulated acute and persistent pathogenicity. PLoS Pathog. 2014, 10, e1004321. [CrossRef] 
48. Whiteley, M.; Diggle, S.P.; Greenberg, E.P. Progress in and promise of bacterial quorum sensing research. Nature 2017, 551, 313-320. [CrossRef] [PubMed]

49. Skindersoe, M.E.; Alhede, M.; Phipps, R.; Yang, L.; Jensen, P.O.; Rasmussen, T.B.; Bjarnsholt, T.; Tolker-Nielsen, T.; Høiby, N.; Givskov, M. Effects of antibiotics on quorum sensing in Pseudomonas aeruginosa. Antimicrob. Agents Chemother. 2008, 52, $3648-3663$. [CrossRef]

50. Tan, S.Y.-Y.; Chua, S.-L.; Chen, Y.; Rice, S.A.; Kjelleberg, S.; Nielsen, T.E.; Yang, L.; Givskov, M. Identification of five structurally unrelated quorum-sensing inhibitors of Pseudomonas aeruginosa from a natural-derivative database. Antimicrob. Agents Chemother. 2013, 57, 5629-5641. [CrossRef] [PubMed]

51. Ahmed, S.A.K.S.; Rudden, M.; Smyth, T.J.; Dooley, J.S.G.; Marchant, R.; Banat, I.M. Natural quorum sensing inhibitors effectively downregulate gene expression of Pseudomonas aeruginosa virulence factors. Appl. Microbiol. Biotechnol. 2019, 103, 3521-3535. [CrossRef] 